\begin{tabular}{ll} 
NASKHI \\
Jurnal Kajian Pendidikan dan Bahasa Arab \\
$\begin{array}{ll}\text { Volume 3, No. 2, 2021 } \\
\text { ISSN (print) : 2527-5747 } \\
\text { ISSN (online) : 2716-3369 } \\
\text { Homepage : https://journal.iaimsinjai.ac.id/index.php/naskhi }\end{array}$ \\
\hline
\end{tabular}

\title{
Lingkungan Berbahasa Arab di Madrasah Aliyah Bilingual Batu
}

\author{
البيئة العربية في المدرسة العالية ثنائية اللغة باتو \\ Muhammad Dalle ${ }^{1}$, Muhammad Jundi ${ }^{2}$ \\ ${ }^{1}$ UIN Maulana Malik Ibrahim, Jalan Raya Ir. Soekarno No.1, Kec. Junrejo, Kota Batu \\ ${ }^{2}$ IAIN Sultan Amai, Jl. Sultan Amai Pone, Limboto Barat, Kab. Gorontalo \\ E-mail: jundijundi10@gmail.com Tlp:+6285340076021 \\ DOI: https://doi.org/10.47435/naskhi.v3i2.662
}

This work is licensed under a Creative Commons Attribution-ShareAlike 4.0 International License.

\begin{abstract}
In general, Arabic-speaking environments are only found in Islamic boarding schools, but increasingly this kind of program is also developing in non-Islamic boarding school environments. Not only making Arabic the language learned in class, but also applying it widely in the school environment. In Batu City, East Java, there is a private Bilingual Islamic High School that focuses on familiarizing Arabic and English for its students with a series of achievements in the field of language. This study aims to reveal how to create an Arabic-speaking environment in the Bilingual Islamic High School Batu City. A qualitative approach is used with the type of case study and data taken through interviews and observations. Data analysis uses the Miles and Huberman model which includes 3 stages, namely Data Reduction, Data Display, Conclusions or Drawing or verifying. This study found that the language environment in the Bilingual Islamic High School Batu City was realized through a planned and structured strategy implemented by all elements in the school environment. Especially teachers who always foster the spirit of speaking Arabic in students and familiarize themselves with the use of Arabic in their interactions with students. So that the interaction between students is also carried out in Arabic. Teachers are also active in carrying out efforts to improve student achievement in the form of language development and participation in competitions or internal and external school activities.
\end{abstract}

Keywords: Arabic, Environmental, Bilingual and Islamic School 


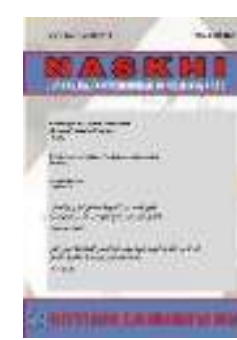

NASKHI

Jurnal Kajian Pendidikan dan Bahasa Arab

Volume 3, No. 2, 2021

ISSN (print) : 2527-5747

ISSN (online) : 2716-3369

Homepage : https://journal.iaimsinjai.ac.id/index.php/naskhi

Umumnya lingkungan berbahasa Arab hanya terdapat di pesantren, namun semakin hari program semacam ini juga turut berkembang di lingkungan madrasah non-pesantren. Tidak hanya menjadikan bahasa Arab sebagai bahasa yang dipelajari di kelas, tetapi juga menerapkannya secara luas di lingkungan sekolah.. Di Kota Batu Jawa Timur terdapat sebuah Madrasah Aliyah Bilingual swasta yang fokus pada pembiasaan bahasa Arab dan Inggris bagi siswanya dengan sederet prestasi para siswanya di bidang kebahasaan. Penelitian ini bertujuan untuk mengungkap bagaimana cara menciptakan lingkungan berbahasa Arab di Madrasah Aliyah Bilingual Kota Batu?. Digunakan pendekatan kualitatif dengan jenis studi kasus dan data diambil melalui wawancara dan observasi. Analisis data menggunakan model Miles dan Huberman yang meliputi 3 tahap, yaitu Data Reduction, Data Display, Conclusions or Drawing or verifying. Penelitian ini menemukan bahwa lingkungan berbahasa di Madrasah Aliyah Bilingual Kota Batu terwujud melalui strategi terencana dan terstruktur yang dilaksanakan oleh seluruh elemen yang ada di lingkungan sekolah tersebut. Utamanya guru-guru yang selalu menumbuhkan semangat berbahasa Arab pada diri siswa dan membiasakan penggunaan bahasa Arab dalam interaksi mereka dengan para siswa. Sehingga interaksi antara siswa pun juga dilakukan dengan bahasa Arab. Guru juga aktif melaksanakan upaya-upaya meningkatkan prestasi siswa-siswanya dalam bentuk pembinaan bahasa serta keikutsertaan pada lomba atau kegiatan internal sekolah maupun eksternal.

Kata Kunci: Bahasa Arab, Lingkungan, Bilingual dan Madrasah

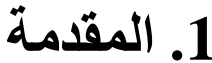

هنالك عو امل عديدة تؤُثر في سرعة اكتساب الفرد للغة الثانية. و على سبيل

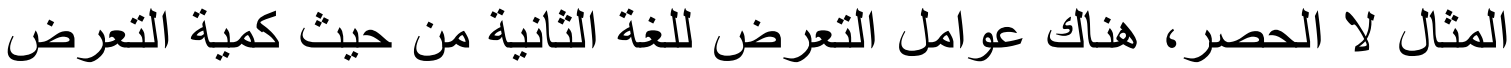

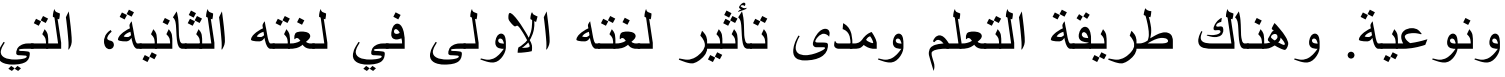

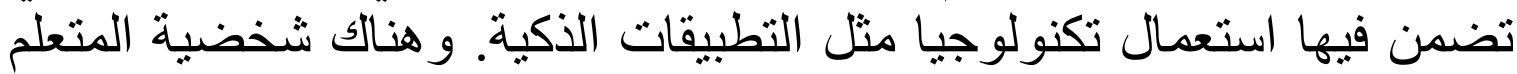

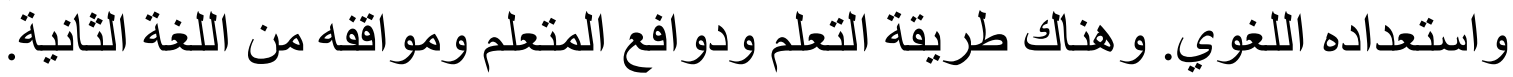

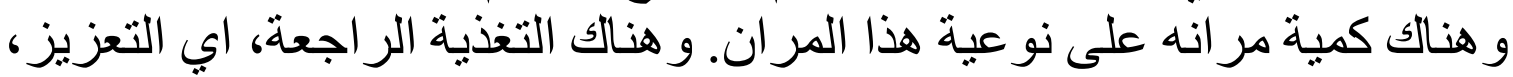

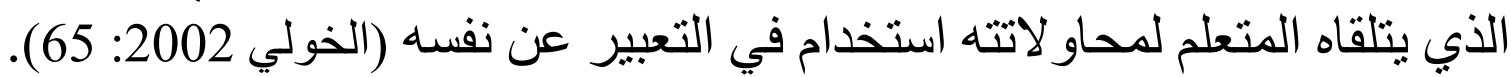

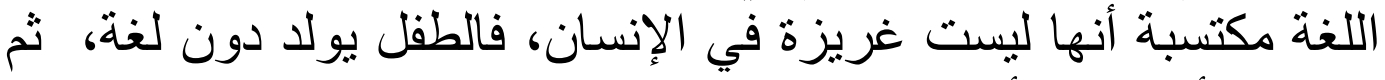

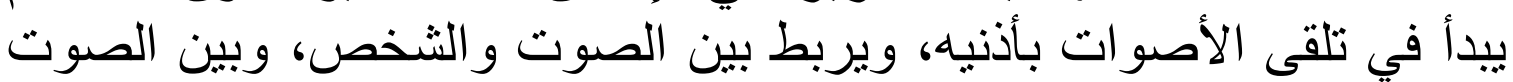

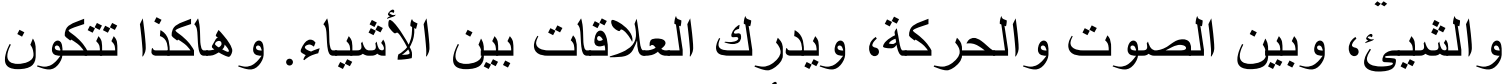

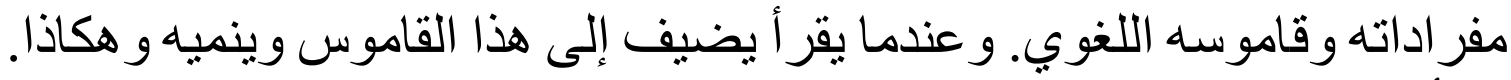

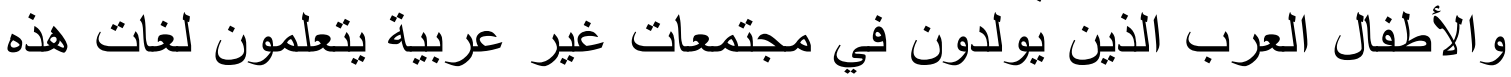

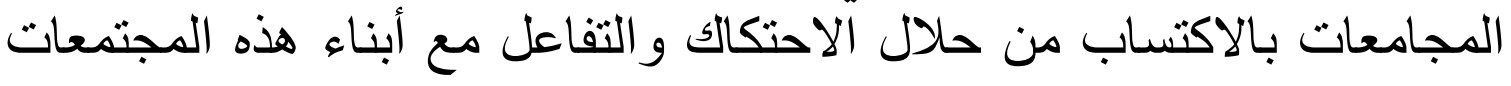

$$
\text { و وثقافاتها (مدكور 2002: 25 25). }
$$

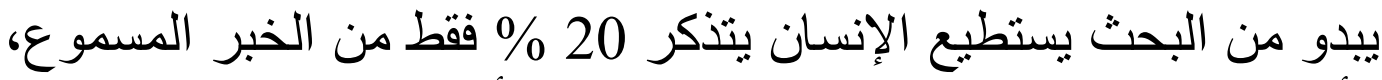
يستطيع أن يتذكر 30 \% من الخبر المشهود يستطيع أن يتذكر 50 \% من الخير الخبرع 


\section{- NASKKI}

Jurnal Kajian Pendidikan dan Bahasa Arab

Volume 3, No. 2, 2021

ISSN (print) : 2527-5747

ISSN (online) : 2716-3369

Homepage : https://journal.iaimsinjai.ac.id/index.php/naskhi

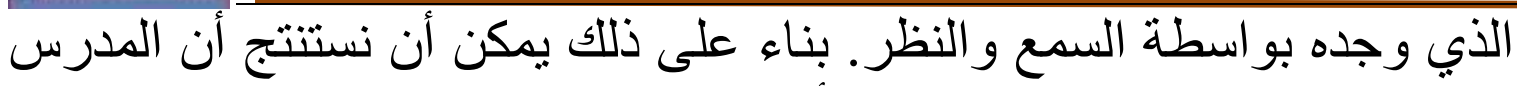

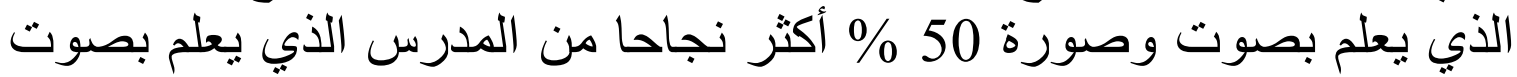

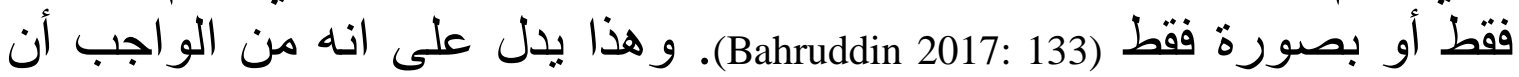
يطبق الكلام العرية في بيئة الفصل و المدرسة كي تعود التلاميذ منها.

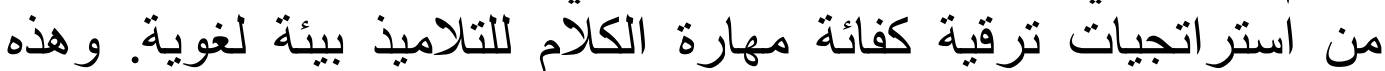

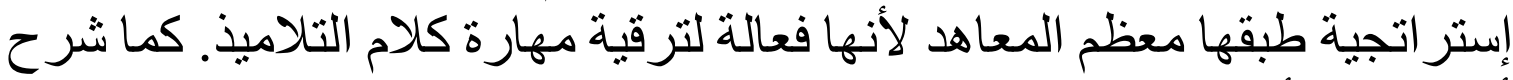
أكما جينيتا أن هنالك علاقة بين بية لغوية ومهارة كلام التلاميذ (Jenita, 2021:71).

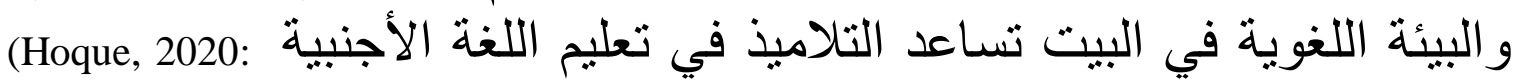

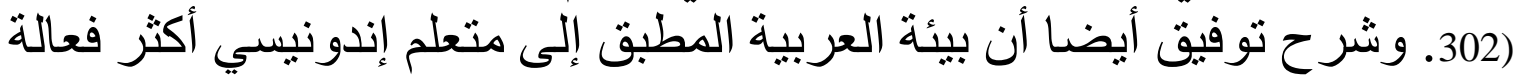

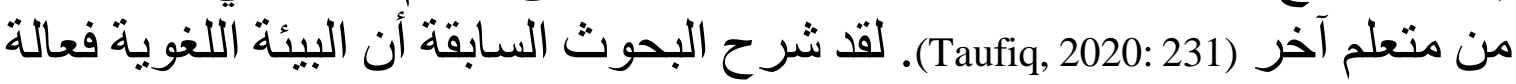
في ترقية مهارة الكلام ولكن هذا البحث سيركز على الاستراتجيات تنفذها المدرسة في قيامها. بناء على خلفية البحث السابقة، فأسئلة البحث هي كيف خلق البيئة العربية

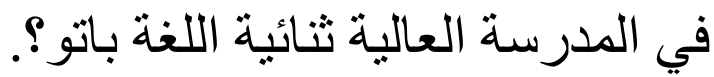

2. 2نهج البحث فيثة

استعمل الباحث في هذا البحث المدخل الكيفي هو المدخل الذي يقرر

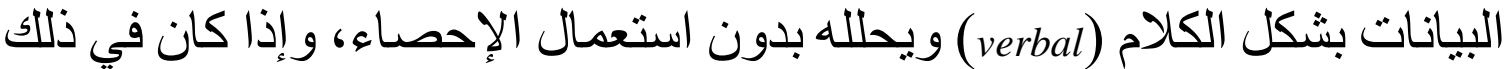

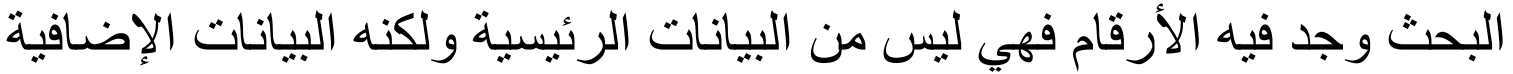

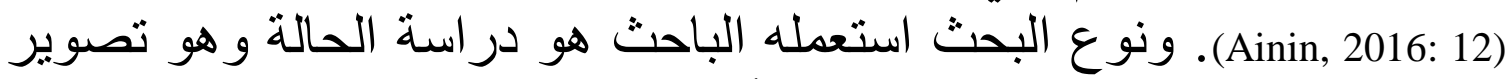
الحالة حسب ما قبضه الباحث من خبرة أو فكرة المشاركين عن حالة الة ما. بتركيز

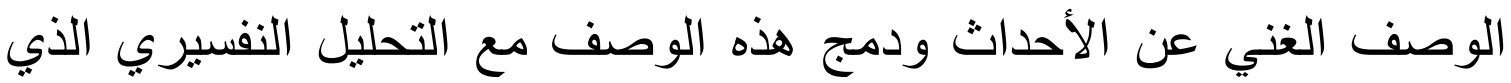

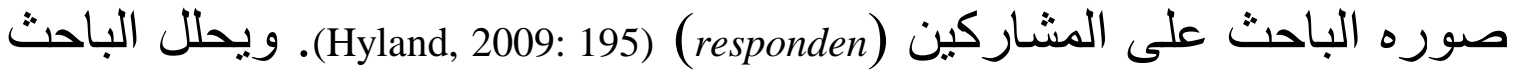
البيانات في هذا البحث بنموذج ميلس وهير البردان أن تحليل البيانات يتكون من

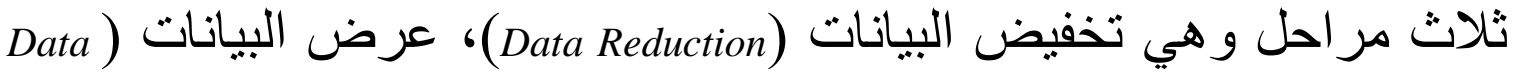
(Sugiyono, 2016: (Conclusions or Drawing or verifying) (Display)

.337) (Miles \& Huberman, 1994) 


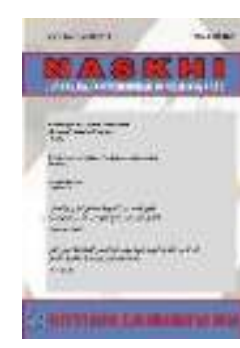

Jurnal Kajian Pendidikan dan Bahasa Arab

Volume 3, No. 2, 2021

ISSN (print) : 2527-5747

ISSN (online) : 2716-3369

Homepage : https://journal.iaimsinjai.ac.id/index.php/naskhi

\section{3. تتائج البحث ومناقشثها \\ أ. خلق البيئة العربية المحيطة في المئية المدرسة \\ النظرية ألبئية}

قال بحر الدين هي التى تفسر اكتساب اللغة وتعلمها على أنه وليد البيئة

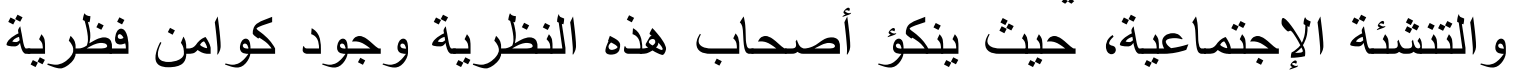

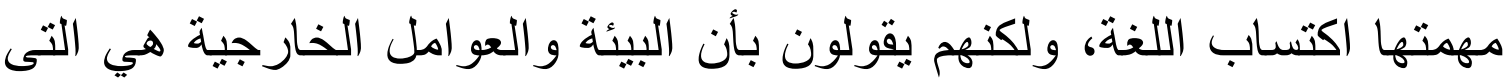

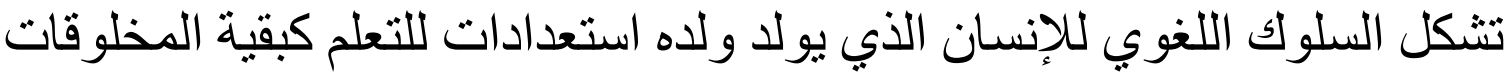

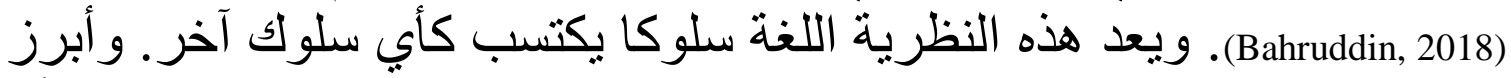
مثل على هذه النظريات: المدرسة السلوكية. يعتقد اصحاب هذه الفهابة المدرسة بأن

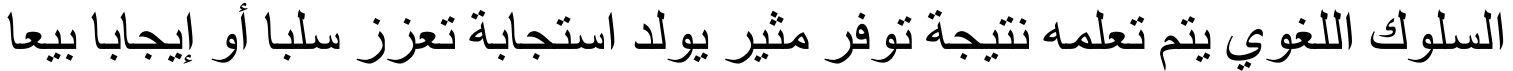

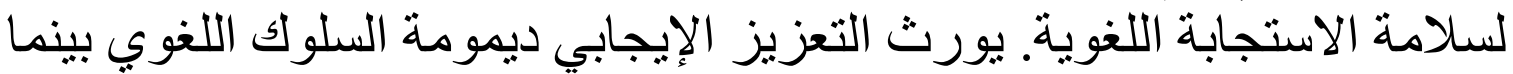

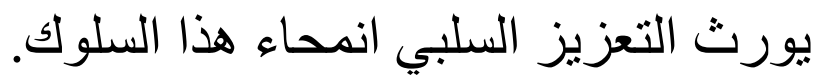
هنالك من النظريات المعاصرة التى تقع تحت مظلة النظريات البيئية وهي

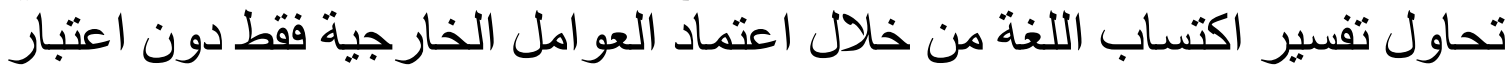

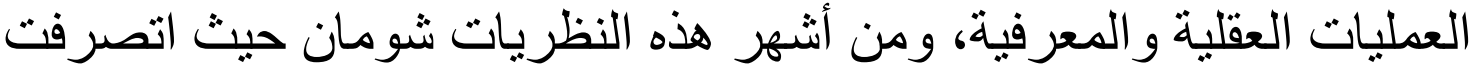

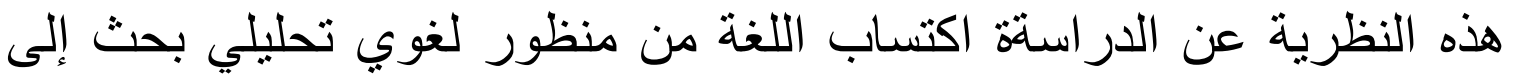

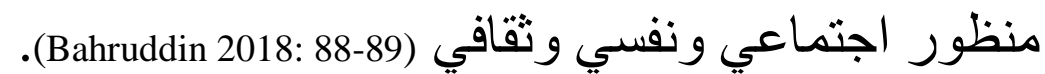

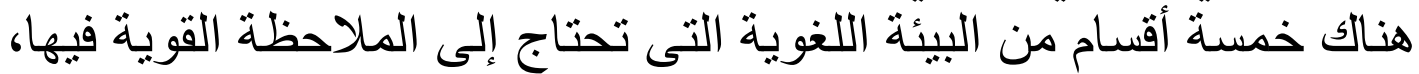

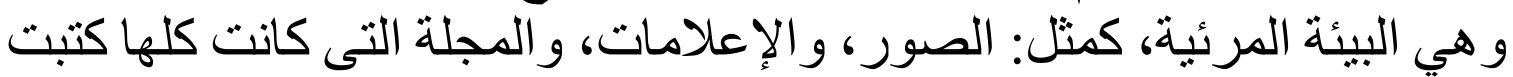

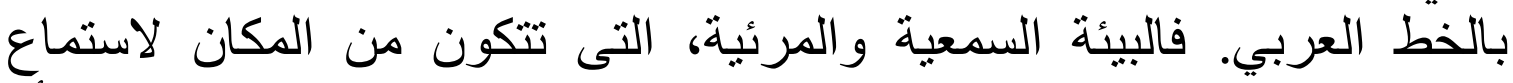

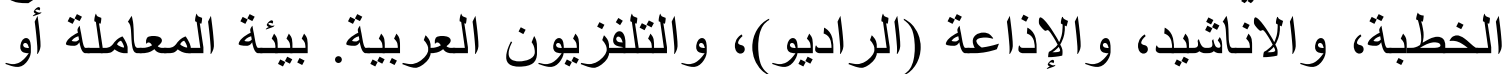

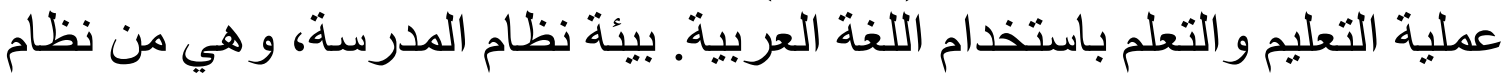

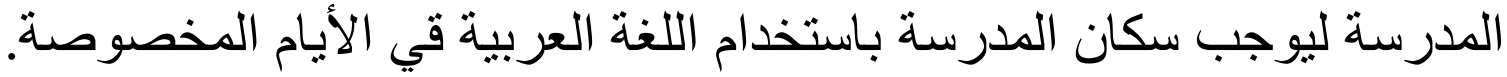
البيئة النفسية الفعالة، وهي تكوين صورة إيجابية للغة العربية Rosyidi and

.Ni'mah, 2011: 13)

\section{البيئة العربية}

بييئة اللغة العربية هي جميع الاشياء و العو امل المادية و المعنوية التى دن فن شأنها أن تاثر في عملية التعليم وترغب هيت الطلاب في تركية اللغة العربية وتدفعهم

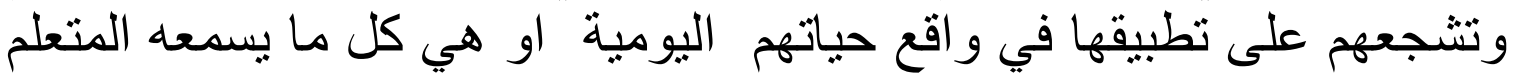
و ما يشـاهده من المؤثر ات المهيئة والإمكانات المحيطة بـه المتعلقة باللغة العربية 


\section{$-\ldots$ NASKHI}

Jurnal Kajian Pendidikan dan Bahasa Arab

Volume 3, No. 2, 2021

ISSN (print) : 2527-5747

ISSN (online) : 2716-3369

Homepage : https://journal.iaimsinjai.ac.id/index.php/naskhi

الكدروسة، و التى ان تأثر في جهوده للحصول على النجاح في تعلم وتعليم اللغة

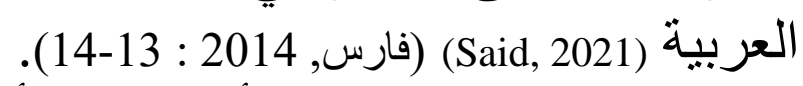

النظرية السلوكية ترى أن المتعلم تأثزره الحو ادث في بيئاته، الذي سيعطى الني

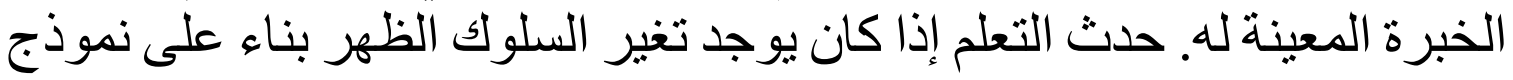

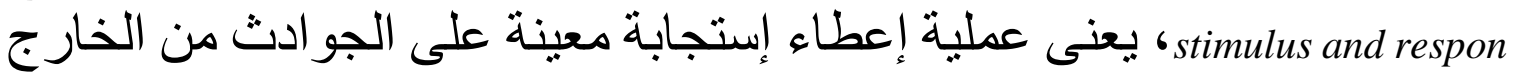

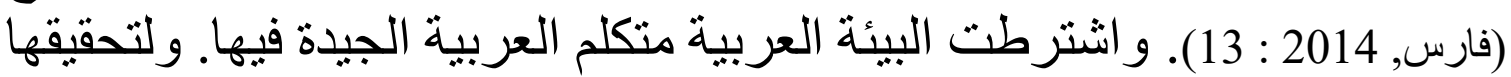

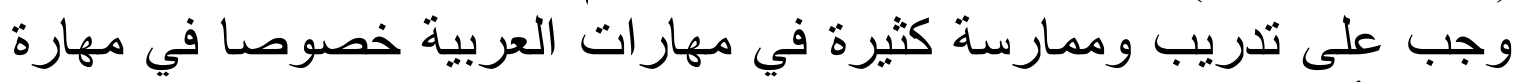

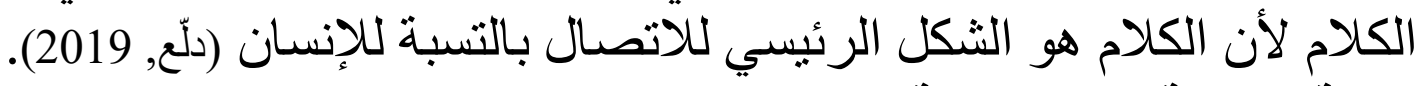

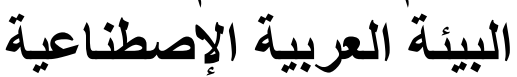
البيئة العربية في المدرسة الاصنة

تهدف المدرسة إلى مساعدة طلابها على النمو السوي جسميا، اجتماعيا،

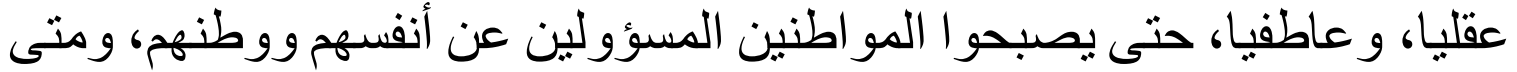

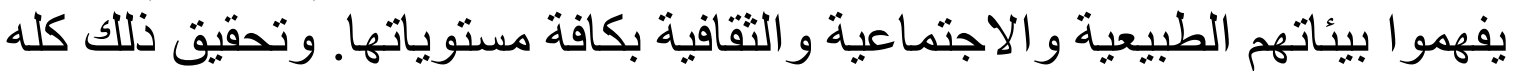

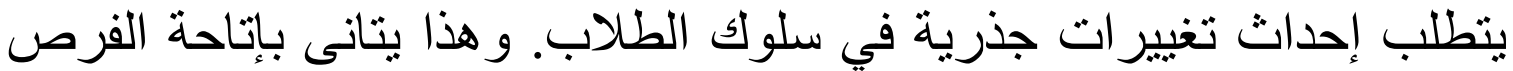

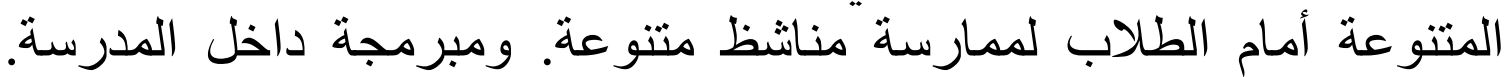

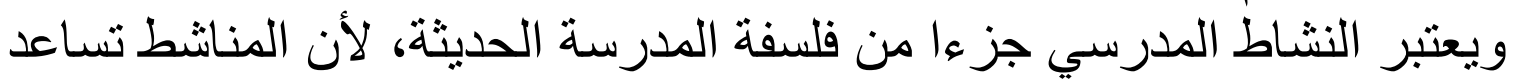

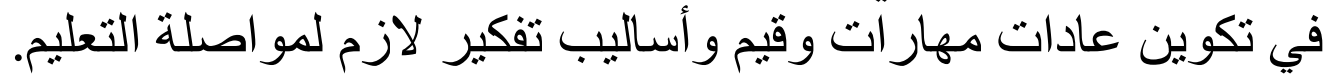

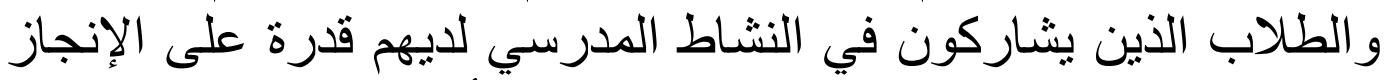

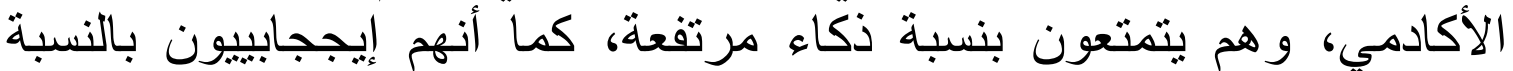

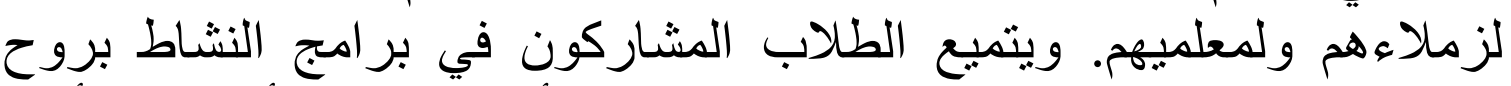

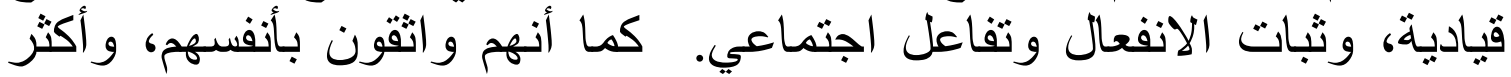

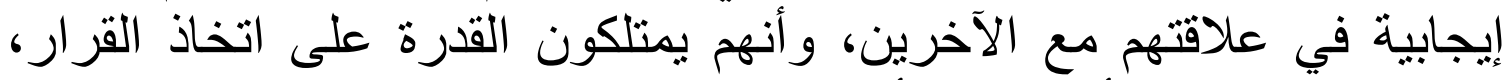

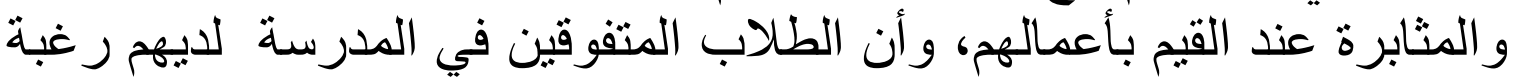

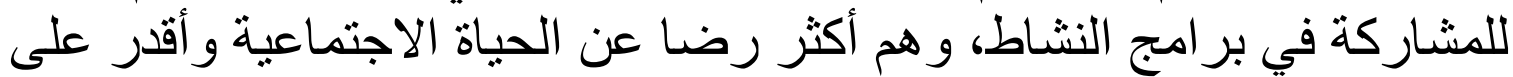

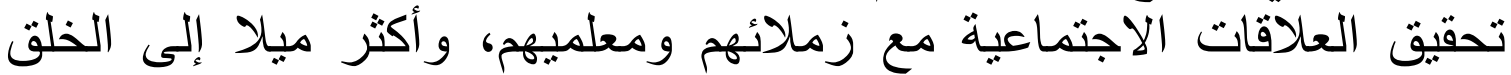

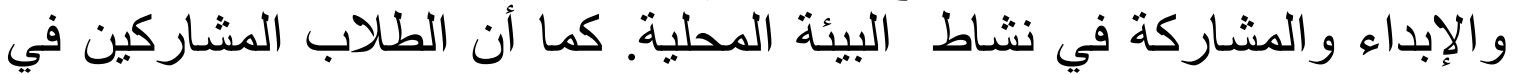

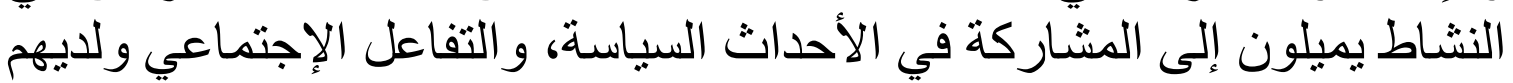
ثقة أكبر في الناس و المدرسة و العالمين فيها لثيا (شحاتة 1992 : 269).

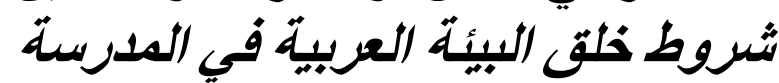

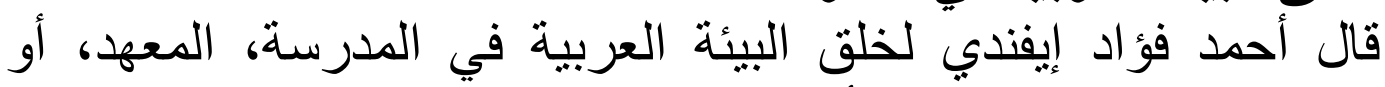

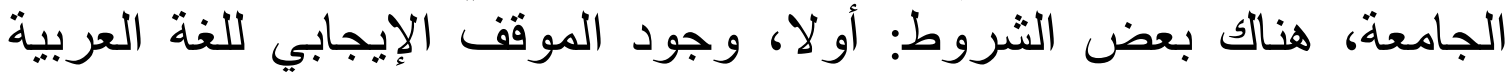




\section{NASKHI}

Jurnal Kajian Pendidikan dan Bahasa Arab

Volume 3, No. 2, 2021

ISSN (print) : 2527-5747

ISSN (online) : 2716-3369

Homepage : https://journal.iaimsinjai.ac.id/index.php/naskhi

و التمسك الثديد لترقى تعليم اللغة العربية من كل جانب، 1 ) معلم اللغة العربية،

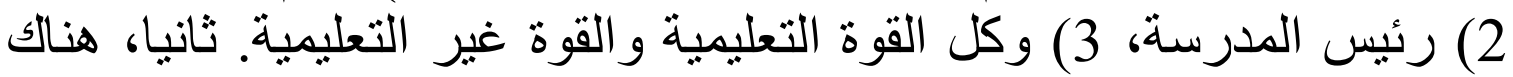

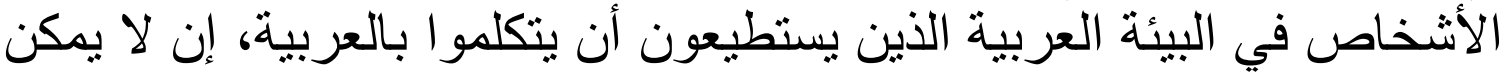

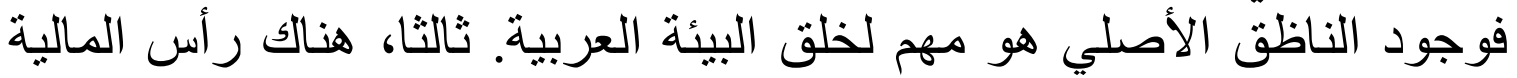
الو افي لأداء المر افق المحتاجة لخلق البيئة العربية (Effendy 2017: 27). نوعا البيئة اللغوية الثاء

البيئة اللغوية نوعان، البيئة اللغوية الرسمية (formal) و البيئة اللغوية غير فئية

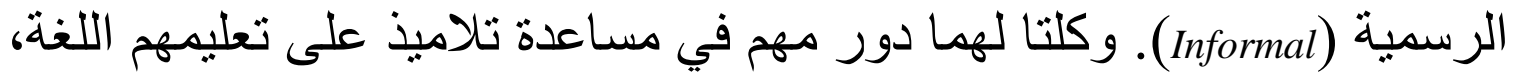

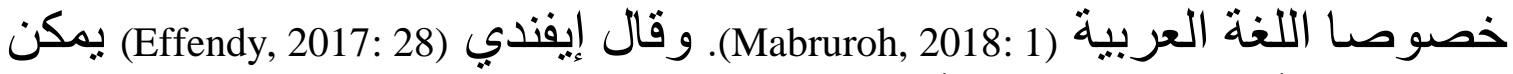
البيئة formal أن يفيد الاكتساب أو مفهوم اللغة (ليس فقط معرفة اللغة ولئة ولكن مهارة

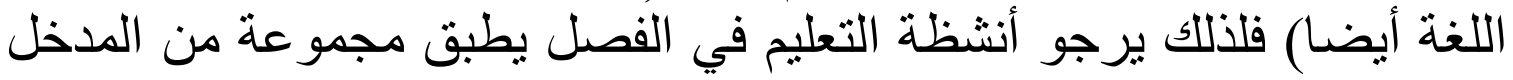

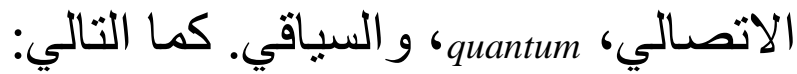

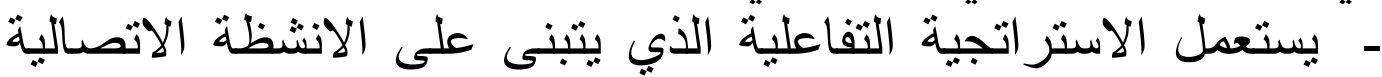

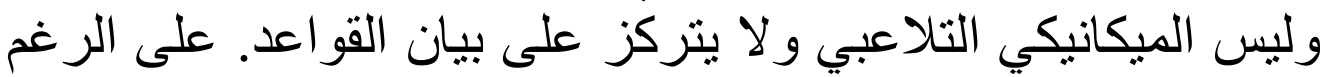

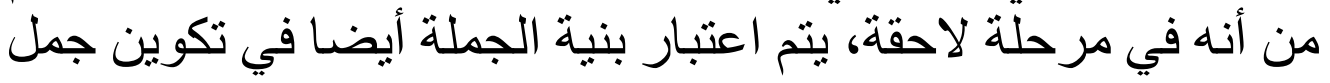
جيدة (Jundi, 2020: 107).

يستعمل المادة المتنوعة بزيادة مواد أصيلة و إيلاء الاهتمام لمبادئ الجدوى و الاستخدام و الجاذبية.

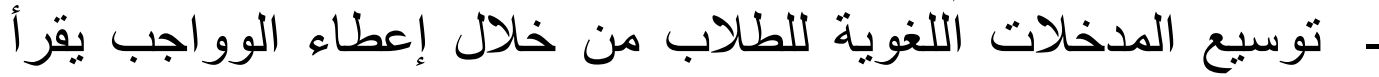

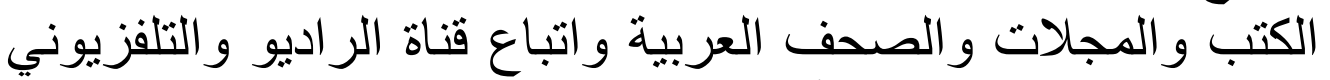

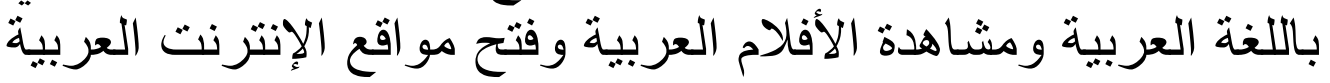
وما إلى ذللك.

- - إعطاء دور للطلاب للتواصل ، في حين أن المعلم لا يتحدث كثيرًا و ولكنه يقوم بالتو جيه و التيسير. - - من الممكن أن يستخدم اللغة العربية على الرئية الرغم من أن يستخدم اللغة

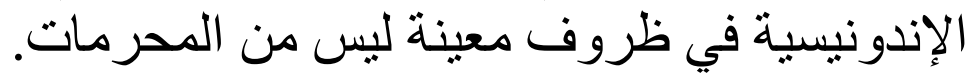

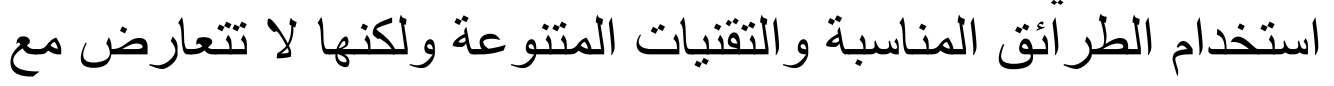

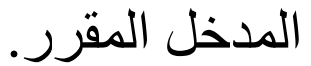
ـ ـ تصميم وتنفيذ الأنشطة العديدة الداعمة. مثل التدريبات على الإنشاء

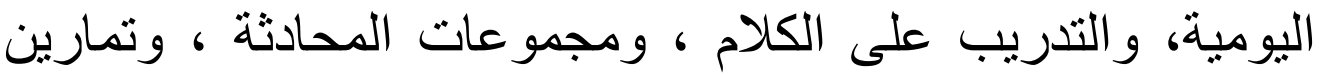
المقابلات، و التعرض المفردات، وما شابه ذللك. 


\section{$-\ldots$ NASKHI}

Jurnal Kajian Pendidikan dan Bahasa Arab

Volume 3, No. 2, 2021

ISSN (print) : 2527-5747

ISSN (online) : 2716-3369

Homepage : https://journal.iaimsinjai.ac.id/index.php/naskhi

أما البيئة اللغوية غير الرسمية (informal) لدى المتعلم الاندونيسي إنه بلدان

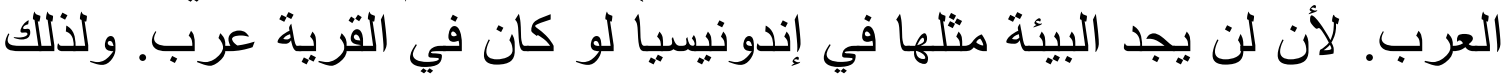

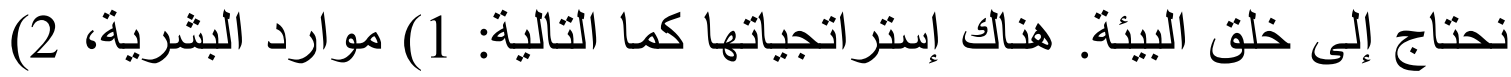

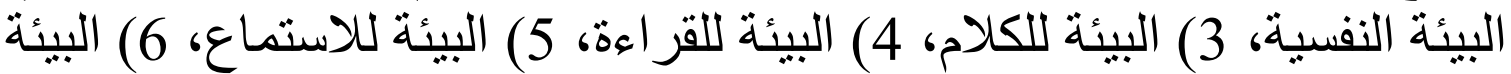

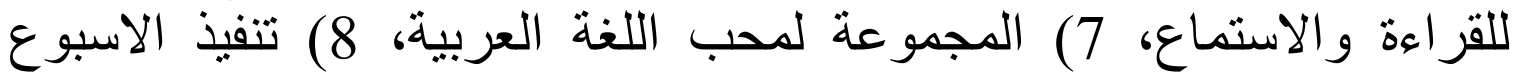

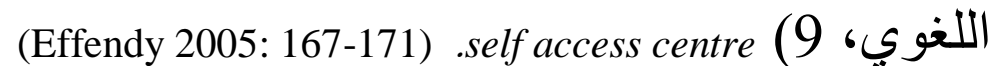
ب.خلق البيئة العربية المحيطة في المدرسة العالية ثنائية اللغة باتو

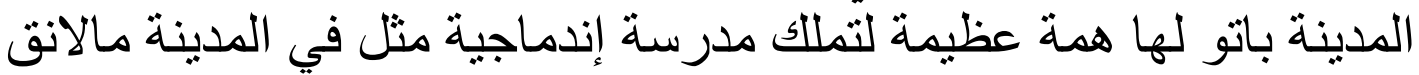

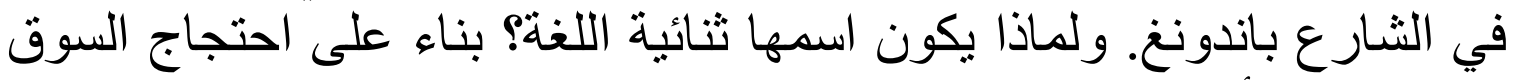

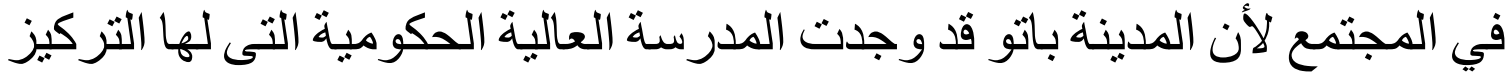

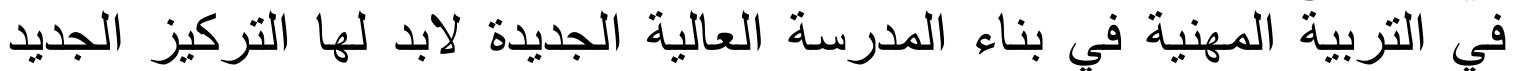

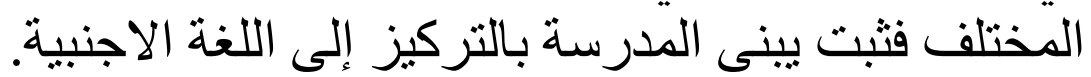

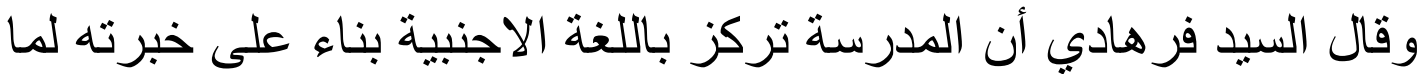

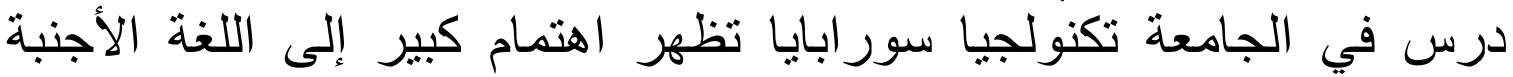
الانجلزية، "لن يتخرج طلابها حتى ناجحون في الاختبار اللغة الإنجليوية الإية الإية

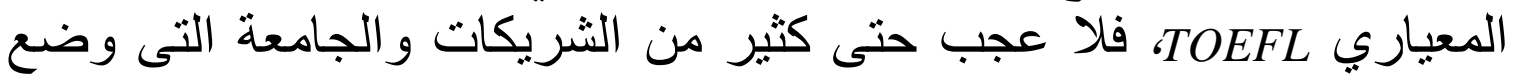
اعتمادهم بالجامعة تكنو لجيا سور ابايا".

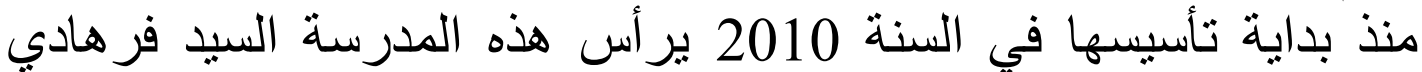

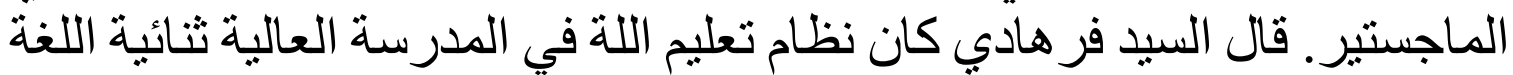

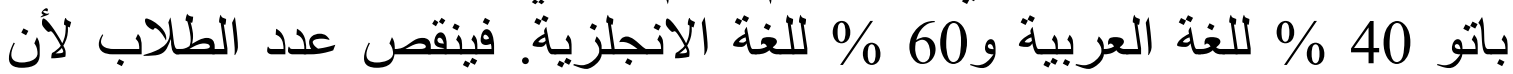

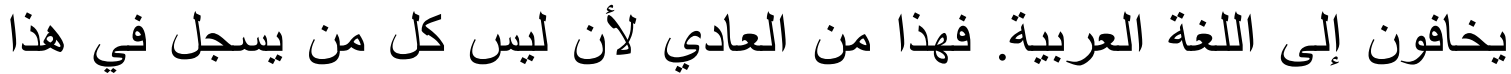

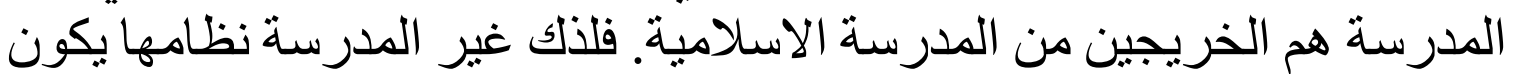
20 \% للغة العربية و 80 \% م للغة الإنجلية.

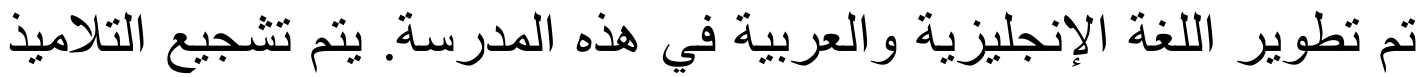

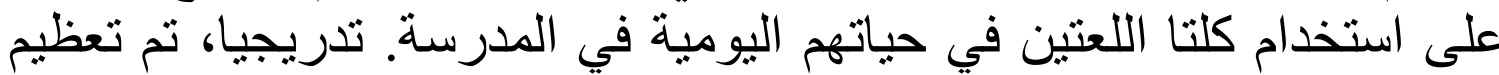

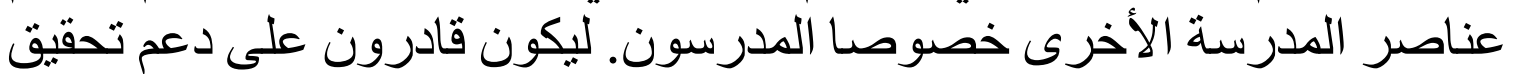
البيئة اللغوية الجيدة في هذه المدرسة.

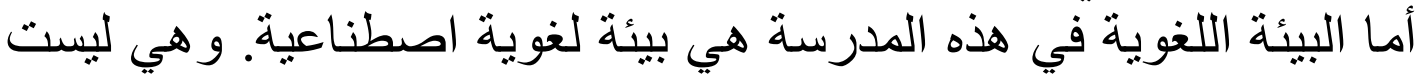

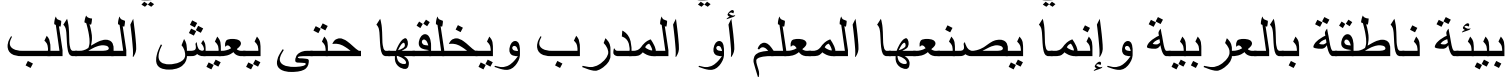

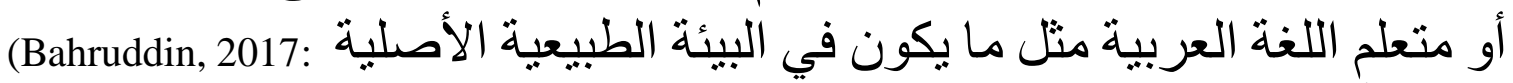

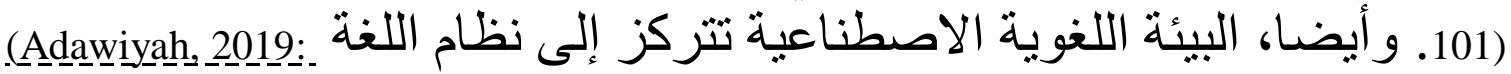




\section{NASKHI}

Jurnal Kajian Pendidikan dan Bahasa Arab

Volume 3, No. 2, 2021

ISSN (print) : 2527-5747

ISSN (online) : 2716-3369

Homepage : https://journal.iaimsinjai.ac.id/index.php/naskhi

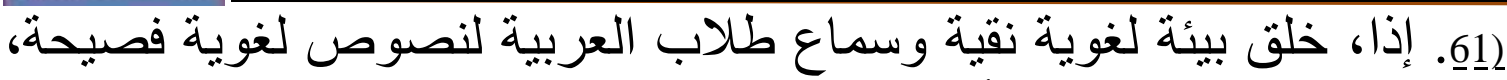

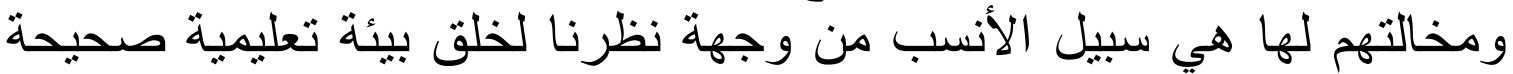

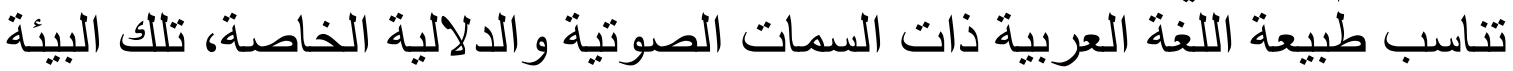
اللغوية تسهم بشكل فعال في عملية تحقيق الضبط اللغوي لدى طلاب العربية ومستخدميها.

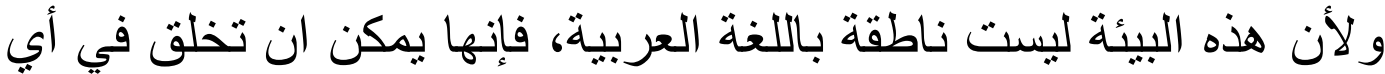

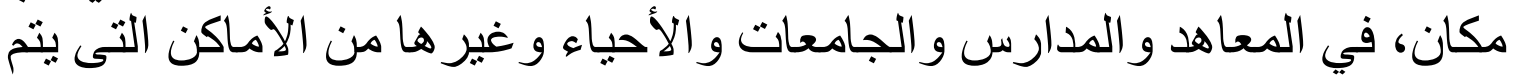

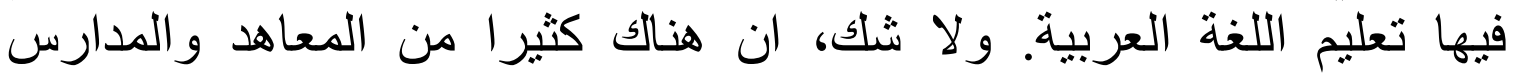

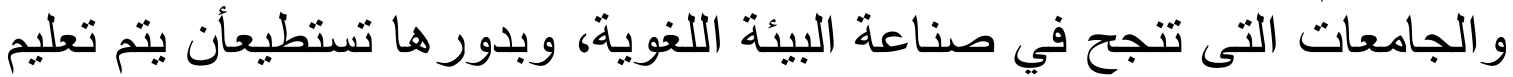

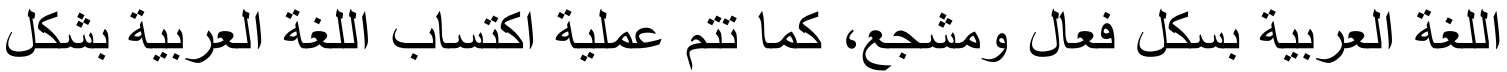

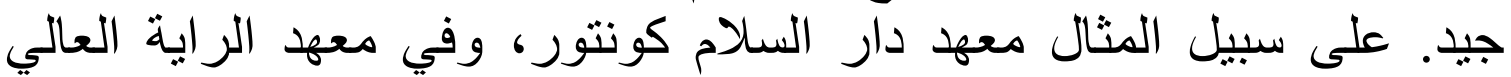

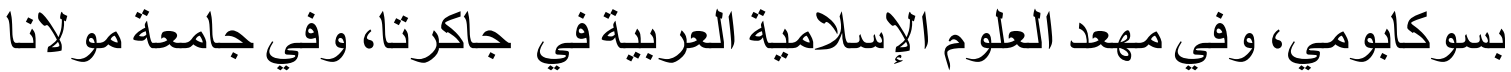

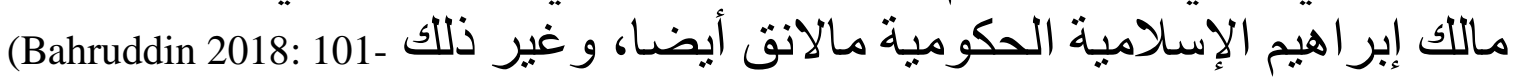

\section{البيئة العربية في المدرسة العالية ثنائية اللغة باتو عامة}

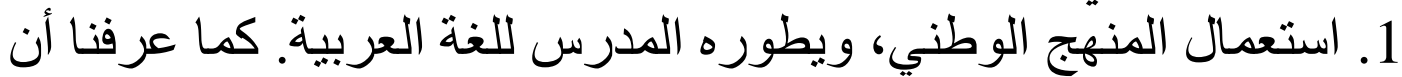

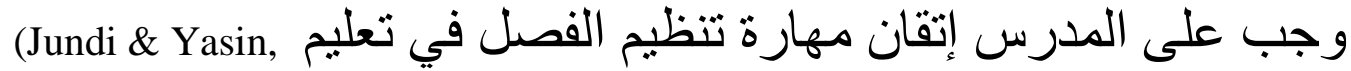

2. الدرس الإضـافي لدى المدرسيين الذين لم بيتو عبو ا باللغة الانجلزية. و هذا

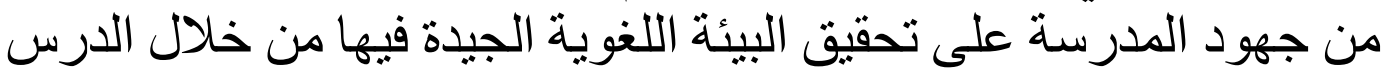

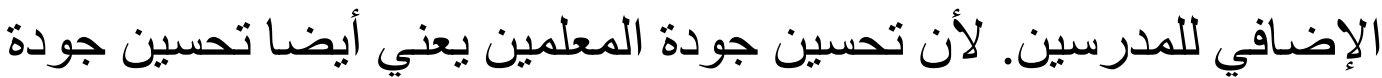
التعليم (Nurhasanah, 2017:50).

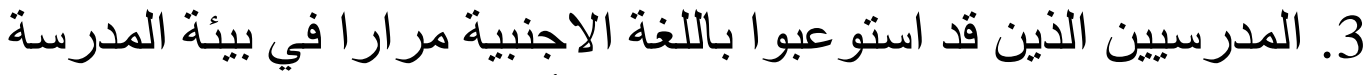

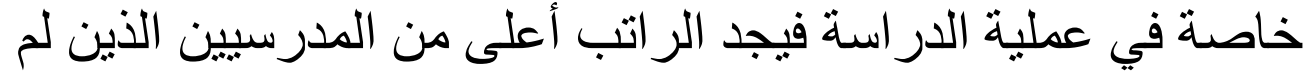
يستو عبو آ باللغة الأجنبية. 4. العو امل المأثرة في ترقية اللغة في بيئة المدرسة هي: المدرس، الإدارة و الإنتاج.

5. في مقدمة المدرس في بداية كلامه لابد بالانجلزية أو بالعربية

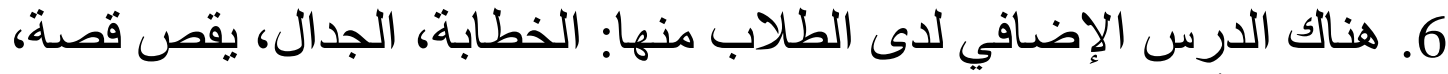

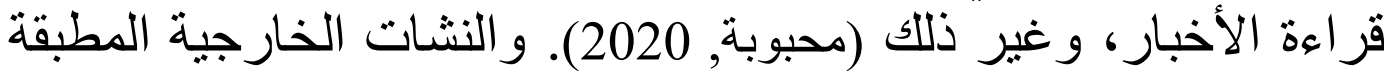




\section{$\therefore$ NASKHI}

Jurnal Kajian Pendidikan dan Bahasa Arab

Volume 3, No. 2, 2021

ISSN (print) : 2527-5747

ISSN (online) : 2716-3369

Homepage : https://journal.iaimsinjai.ac.id/index.php/naskhi

في طرق ونماذج منتو عة تساعد تلاميذ على تحسين المهار ات اللغوية إما

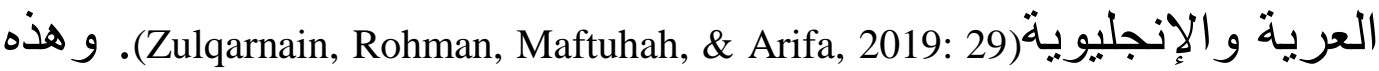

(Khusnah, الأنشطة وجب على ترقيتها لحصول على النتائج القصوية

.Kholisin, \& Nasih, 2020: 13)

7. في آخر كل السنة هناك هدية لمن المدرس يستعمل اللغة الأجنبية

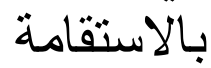

البيئة العربية في عملية تعليم اللغة العربية في الخصة الاراسية (formal)

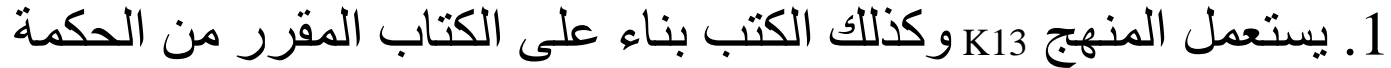

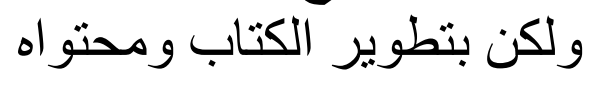

2. تجرى عملية تعليم اللغة العربية في كل الاسبوع الكئل 90 دقيقة لكل الفصل.

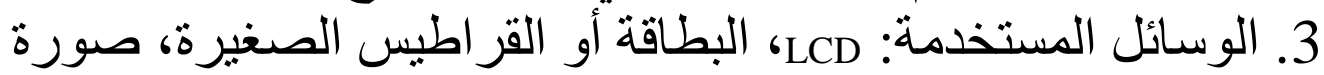

$$
\text { الطبية او الدمية. }
$$

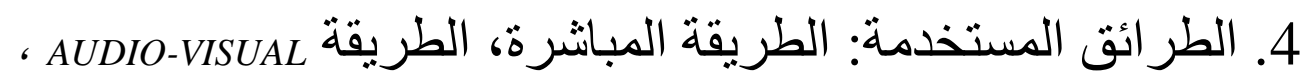

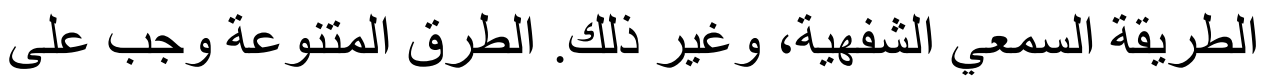

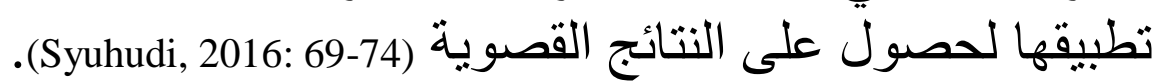
5. و الكتب الذي استعمله الطالب في عملية التعليم هو الكتاب المطور من

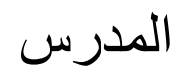

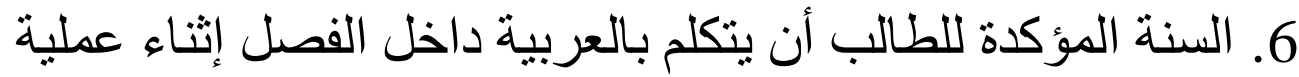

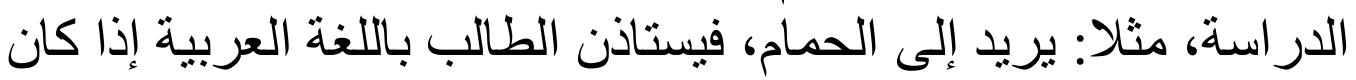
ل الا فلا يجوز له للإذنة.

\section{ه البيئة العربية في عملية تعليم اللغة العربية خارج الخصة الدراسية}

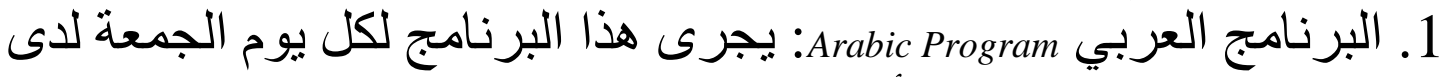

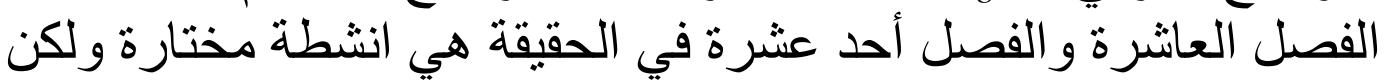

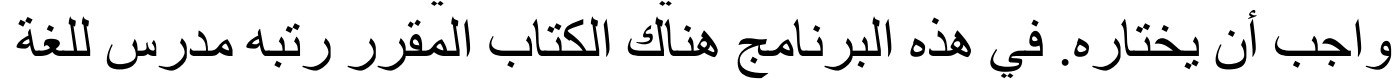

$$
\text { الغربية تتكون محتو أه من العربارة اليومية. }
$$

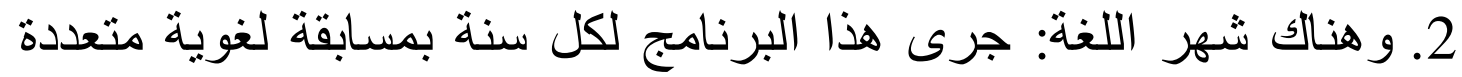

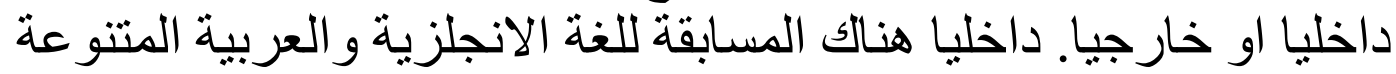

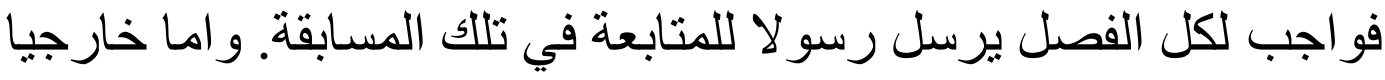

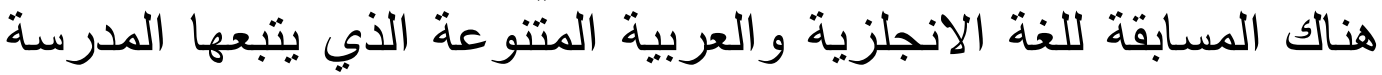
الثانوية في كل أنهاء مالانق رائا. 


\section{$-\ldots$ NASKHI}

Jurnal Kajian Pendidikan dan Bahasa Arab

Volume 3, No. 2, 2021

ISSN (print) : 2527-5747

ISSN (online) : 2716-3369

Homepage : https://journal.iaimsinjai.ac.id/index.php/naskhi

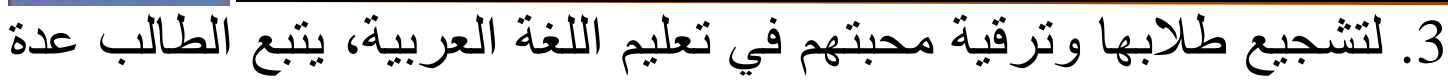

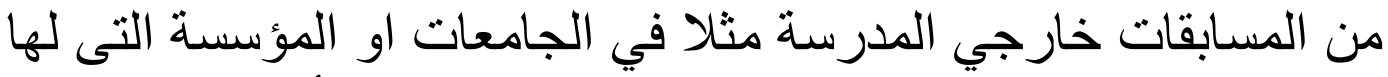

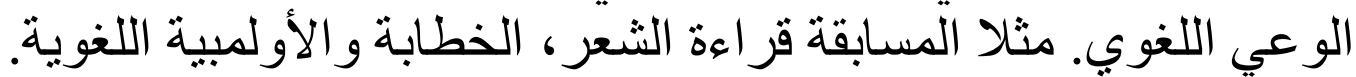

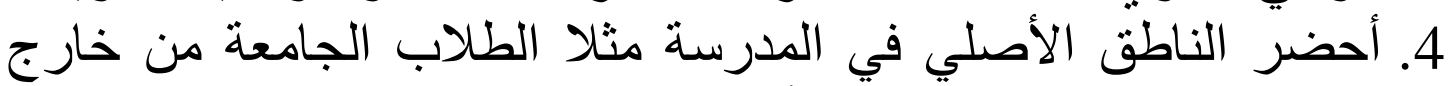

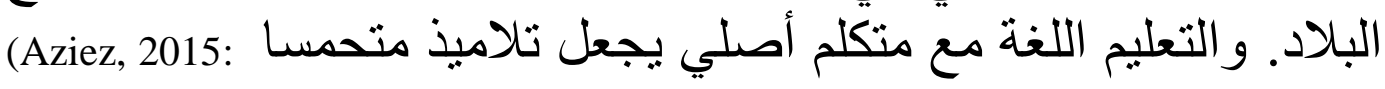

5. وأما الانجاز ات التى قد حققها في 2019 الطلاب المدرسة ثنائية اللغة

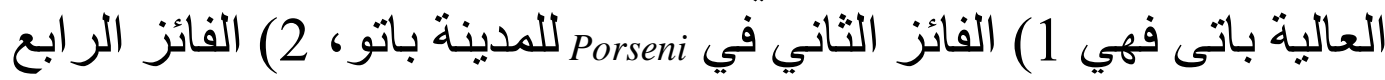

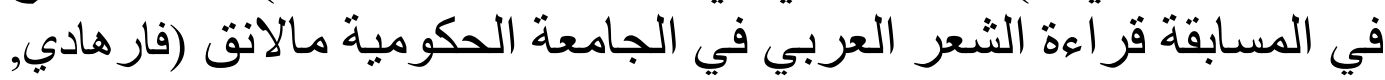

. (2020

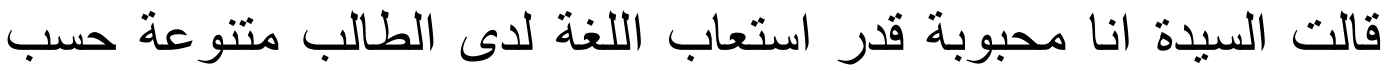

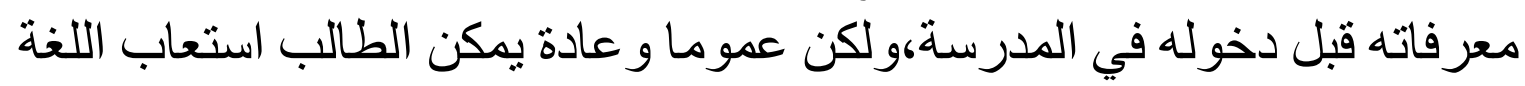
وكذلك يشجعون تطبيقها في الكلام تقريبا يحتاج إلى الوقت السنة الونا لواحدة.

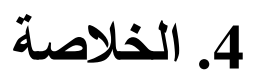

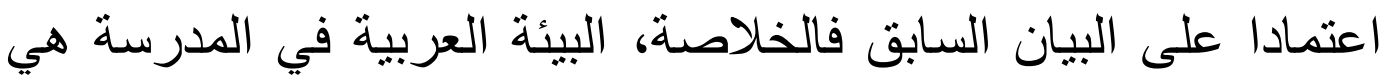

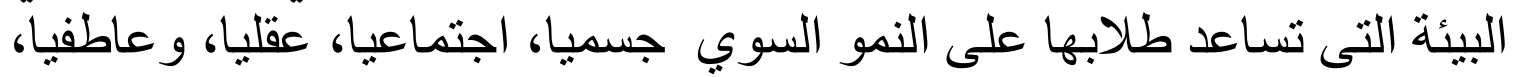

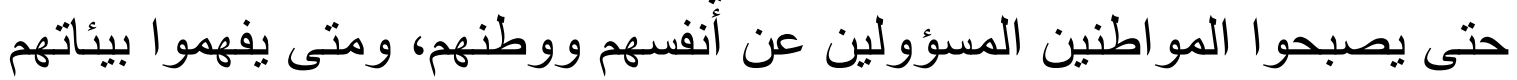

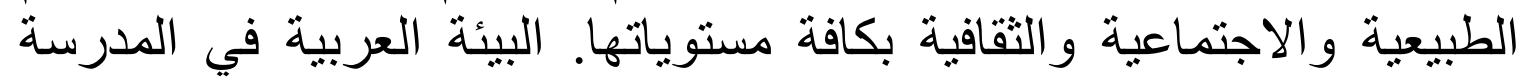

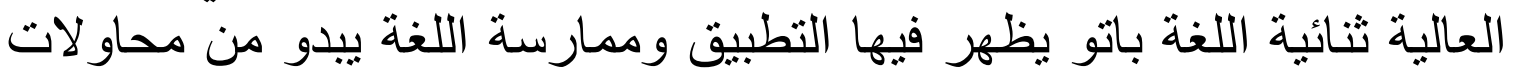

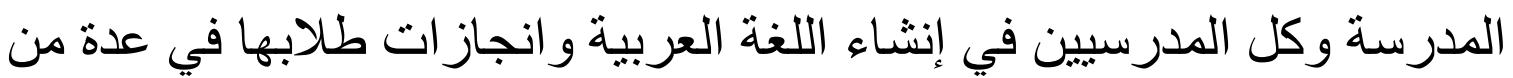

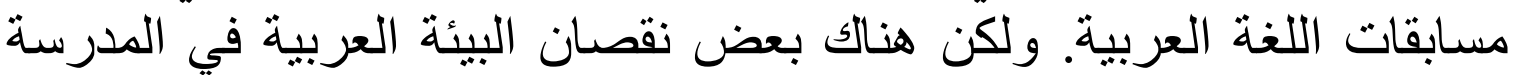

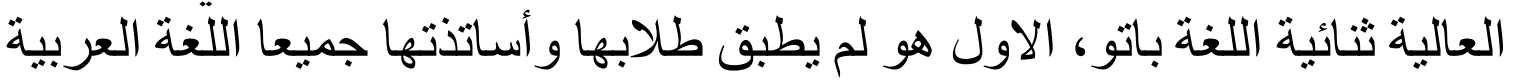

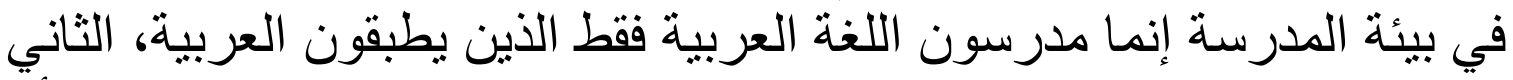

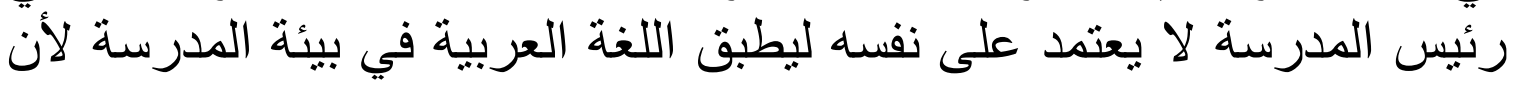

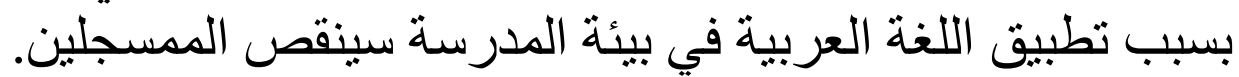

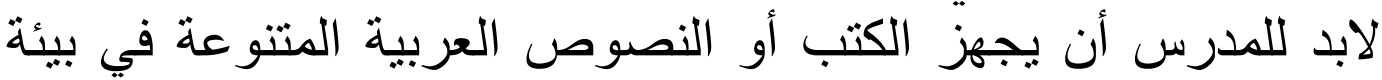

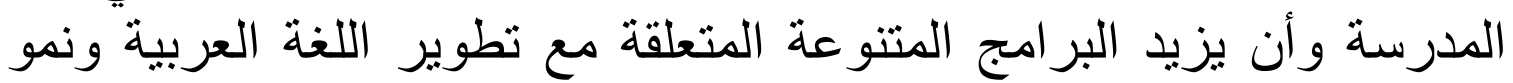

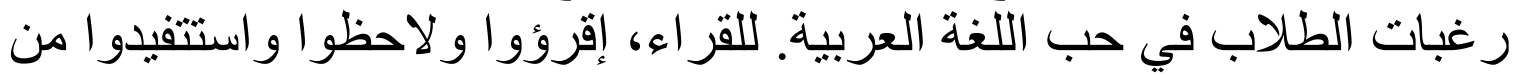

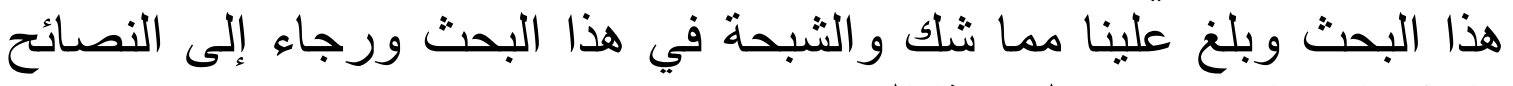

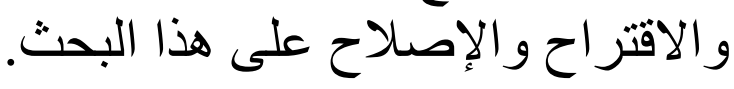


أحمد فارس، بيئة اللغة العربية في تعلبم مهارة الكالام في معهد النقابية الإسالامي ولفي

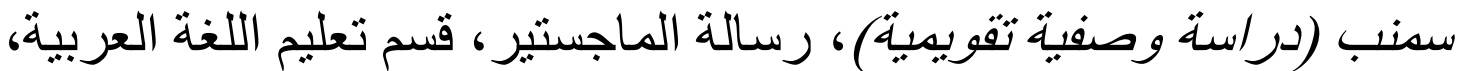

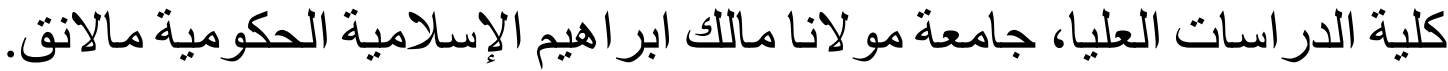

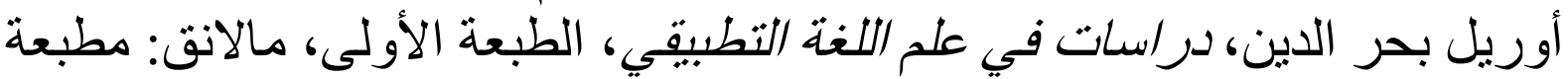

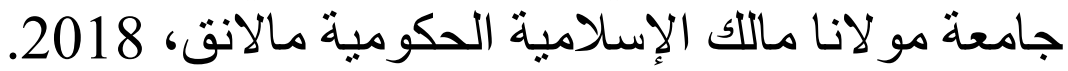
حسن شحاتة، تعلبم اللغة العربية بين النظربية والتطبيق، الطبة مالنة، النبة الثانية، القاهرة:

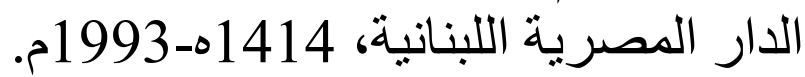

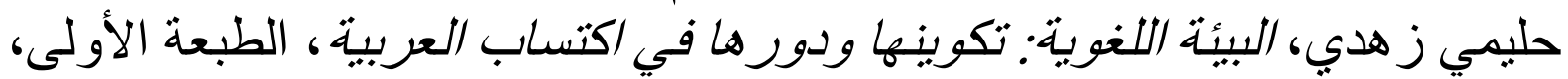

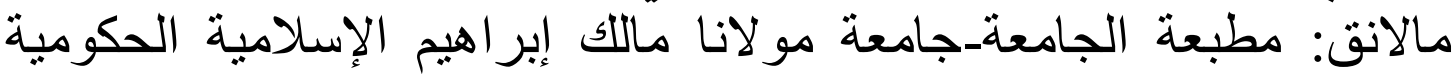

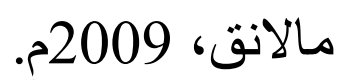
دلّع، محمد. تحليل الأخطاء النحوية و الصرفية في تركيب الكلام (در اسة مقارنة

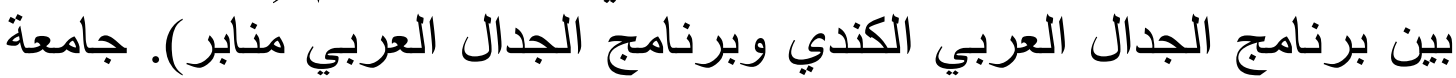

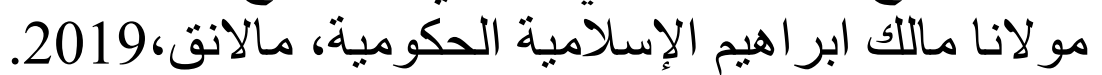

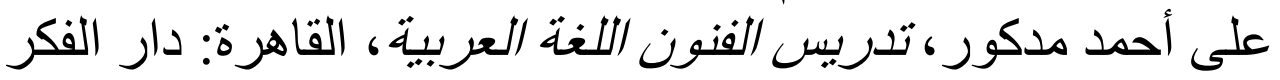

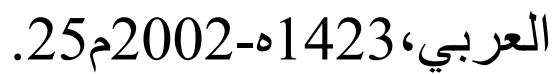

محمد علي الخولي، الحباة مع اللغتبن: الثنائية اللغوية ، الطبعة الاولى، الرياض:

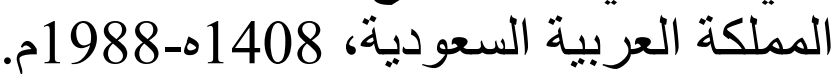

المناقنة مع المدرسة للغة العربية السيدة انا محبوبة، العية، تاريخ 15 أكتوبر 2019 في في

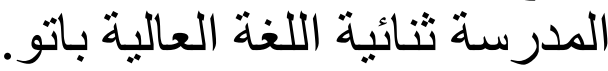

المناقشة مع رئيس المدرسة السيد فار هادي تاريخ 15 أكتوبر 2019 في المدرسة

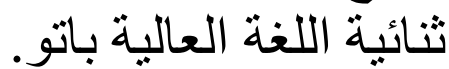

Adawiyah, Yayah Robiatul., (2019). البيئة اللغوية في ترقية مهارة الكلام بمعهد المصدوقية كركسان بروبولنهاتئه IJATL: International Journal of Arabic Teaching and Learning. 3(1)

Ainin. Moh., Metodologi Penelitian Bahasa Arab, Malang: Bintang Sejahtera, 2016

Aziez, Faisal. (2015). Persepsi Mahasiswa terhadap native English Teacher (NET) dalam Mata Kuliah Speaking I da Writing I. Jurnal Tarbawi 12(2)

Bahruddin. Uril, Rekonstruksi Pengembangan Pendidikan Bahasa Arab, Sidoarjo: Lisan Arabi, 2017.

Effendy. Ahmad Fuad, Metodologi Pengajaran Bahasa Arab, Cet. 3, Malang: Misykat, 2005. Hoque, Mesbahul., (2020). دور الأسرة والمدرسة في تنشئة البيئة اللغوية: The Role of the Family and the

School in Creating a Linguistic Environment. 'Abqari Journal 23(1)

Hyland. Ken, Teaching and Researching Writing, ed. 2, Malaysia: Pearson, 2009 


NASKHI
Jurnal Kajian Pendidikan dan Bahasa Arab
Volume 3, No. 2, 2021
ISSN (print) : 2527-5747
ISSN (online) : 2716-3369
Homepage : https://journal.iaimsinjai.ac.id/index.php/naskhi

Jenita, Akma., (2021). Al-'Alaqah baina al-Biah al-Lugawiyah al-'Arabiyah wa Maharatu Kalami al-Tullab fi al-Madrasah al-Sanawiyah Sumatra al-Tawalib Parabek Bukit Tinggi. Lisanan Arabiya 5(1)

Jundi, Muhammad., (2020). Persepsi Mahasiswa terhadap Pelaksanaan Perkuliahan Nahwu dengan Sistem Daring. Al-Ma'rifah 17(2)

Jundi, M., \& Yasin, Z., (2020). Penilaian Sejawat dalam Pembelajaran Keterampilan Dasar Mengajar bagi Mahasiswa Pendidikan Bahasa Arab pada Mata Kuliah Pembelajaran Mikro. Maharaat: Jurnal Pendidikan Bahasa Arab, 2(2)

Khusnah, dkk. (2020). Pola Pengembangan Ekstrakurikuler Bahasa Arab di Lembaga Pengembangan Bahasa Asing (LPBA) Pondok Pesantren Nurul Jadid Paiton Probolinggo. Hijai: Journal on Arabic Language and Literature 3(2)

Mabruroh, (2018). البيئة اللغوية العربية في نعليم اللغة العربية لغير الناطقين بها . El-Ibtikar 7(2).

Nurhasanah, Santi., (2017). Pelatihan Peningkatan Kompetensi berbahasa Inggris Guru dalam Pembelajaran Bilingual di SDIT Bilingual Fithrah Insani Kabupaten Bandung Barat. Empowerment: Jurnal Ilmiah Program Studi Pendidikan Luar Sekolah 6(1)

Rosyidi. Abdul Wahab dan Mamlu'atul Hasanah, Memahami Konsep Dasar Pembelajaran Bahasa Arab, Cet. 1, Malang: UIN-Maliki Press, 2011.

Said, MM., نموذج بيئة اللغة العربية بمعهد الإرشاد سمارانج جاوى الوسطى إندونيسيا ودور ها في اكتساب المهارات اللغوية. Tsaqofiya 2(1)

Sugiyono, Metode Penelitian Pendidikan; Pendekatan Kuantitatif, Kualitatif, dan R\&D, cet. 23, Bandung, Alfabeta, 2016

Syuhudi, Abdur Rosyad. (2016) Pemilihan Metode Pengajaran Bahasa Arab yang Efektif. Intelegensia: Jurnal Pendidikan Islam 4(1)

Zulqarnain, dkk., (2019). Model Pembelajaran Ekstrakurikuler Bahasa Arab dan Implementasinya di Madrasah Aliyah Pesantren. Arabiyatuna 3(1) 